\title{
Infectious disease risk in asbestos abatement workers
}

\author{
John H Lange', Giuseppe Mastrangelo ${ }^{2}$ and Luca Cegolon ${ }^{2,3^{*}}$
}

\begin{abstract}
Background: The current literature reports increased infectious disease occurrence in various construction occupations, as an important contributor to morbidity and mortality arising from employment.

These observations should be expanded to asbestos abatement workers, as the abatement can create an environment favorable for bacterial, viral and fungal infections.
\end{abstract}

Discussion: Asbestos abatement work employs activities resulting in cuts, blisters and abrasions to the skin, work in a dirty environment and exposure to dust, mists and fumes.

Furthermore, this population exhibits a high smoking rate which increases the risk of chronic obstructive pulmonary disease and respiratory infections.

In addition, these workers also commonly employ respirators, which can accumulate dirt and debris magnifying exposure to microbes. Use of respirators and related types of personal protective equipment, especially if shared and in the close environment experienced by workers, may enhance communicability of these agents,

including viruses.

Summary: Abatement workers need to be provided with information on hazards and targeted by appropriate health education to reduce the infection risk. Epidemiological studies to investigate this risk in asbestos removers are recommended.

\section{Background}

Several studies [1-5] have reported on increased infectious disease occurrence in various construction occupations, with these agents constituting an important contributor to morbidity and mortality arising from employment.

We believe these observations need to be expanded to asbestos abatement workers, especially since infectious diseases appear to be associated with certain industrial occupations, most notably those in the construction industry.

Respiratory diseases are commonly discussed as a hazard for those employed in the asbestos abatement industry, although focus is on cancer and asbestosis. Recently there has even been a suggestion of exposure to asbestos contributing to cardiovascular disease [6]

\footnotetext{
* Correspondence: I.cegolon@gmail.com

${ }^{2}$ Padua University, Department of Molecular Medicine, Padua, Italy ${ }^{3}$ Imperial College London, School of Public Health, St. Mary's Campus, London, UK

Full list of author information is available at the end of the article
}

with this agent causing disease states in locations other than the lungs and those traditionally identified, especially at high exposure levels [7]. For this group of workers there are periodically discussions of other non-asbestos hazards (e.g. confined conditions, heat disorders, etc.), with the literature rarely mentioning infectious diseases $[8,9]$.

\section{Discussion}

One study [1] reported exposure to inorganic dust, which includes asbestos, for construction workers resulted in a high rate of mortality from infectious pneumonia (relative risk for inorganic dust $=1.87$, with $95 \%$ confidence interval: 1.22-2.89). Since asbestos abatement workers are exposed to both inorganic/mineral dusts and chemicals, it would appear a risk from infectious disease exists and include various forms of infections (e.g. skin) beside mortality from pneumonia as indicated by Thoren [1] for inorganic dust.

A PubMed search of "asbestos abatement and infectious disease", "asbestos abatement and infections", "asbestos workers and infectious disease" or "asbestos workers and 
infections" produced no actual citations; although, one existed as related to fungal exposure during abatement [10]. Today, mold (fungal) exposure during abatement is recognized as a hazard for this type of industry $[11,12]$.

Overall, abatement can create an environment favorable for bacterial and fungal infections [13]. For construction workers, most reports discuss infections related to bacterial or fungal diseases $[3,13,14]$, but have not clearly illustrated how this hazard extends to asbestos-related work. This report may be the first in the open literature expressing the concept of infectious disease risk directly linked to asbestos abatement workers.

Asbestos abatement work employs activities resulting in cuts, blisters and abrasions to the skin, work in a dirty environment and exposure to dust, mists and fumes (i.e. inorganic and mineral dusts). Exposures and operations of this nature place this group (abatement workers in general) at risk for skin and mucous membrane, uro-genital tract, respiratory, gastro-intestinal tract, cutaneous, direct contact, animal reservoirsrelated and inanimate grouped infections as classified by Haagsma [2]. Infection risk in construction as well as in asbestos abatement work should probably be considered similar to other industries' that a lay person may consider riskier in terms of communicable diseases (e.g. underground mining [15-17], agriculture [18,19], cattle farming [20], sewerage work [21-24], infantry in military [25], etc.).

Furthermore, asbestos abatement workers exhibit a high smoking rate (e.g. 70\%) [26], which increases the risk of chronic obstructive pulmonary disease (COPD) and respiratory infections. It has also been observed that even non-smokers exposed to inorganic dust have an increased mortality rate for COPD [27], enhancing the potential of infection.

In addition, these workers also commonly employ respirators, which can accumulate dirt and debris magnifying exposure to microbes. Use of respirators and related types of personal protective equipment, especially if shared and in the close environment experienced by workers, may enhance communicability of these agents, including viruses. Moreover dermatitis from various causes (e.g. chemical and infectious agents) is a concern [28].

With these findings, type of work performed by abatement workers and their high rate of smoking, it appears this occupational group is at increased risk for various types of infectious disease, including those associated with the pulmonary system.

This hazard may be of even greater importance for asbestos abatement workers in terms of health consequences (e.g. emerging as an important risk factor) since current exposure to asbestos has been shown to be low and there is now little risk of asbestos-related disease for this population (asbestos abatement workers - in the western world) [29,30].

When discussing non-asbestos disease hazards for this occupational population, infectious (microbial) agents should be included along with hygiene practices related to prevention. Abatement workers need to be provided with information on hazards and prevention of infectious disease and dermatitis; the Internet can be a very helpful resource in this complex and changing field if used efficiently [31]. Personnel also need to be targeted by health education aimed at reducing the infection risk [32]. Decontamination and hand washing would appear to be of great importance, but is not the only form of protection/prevention available (e.g. disinfection agents), especially for dermatological and gastro-intestinal risks/ hazards. Abatement workers have routine physical examinations primarily focusing on the pulmonary system and the ability to use a respirator. However, in many cases this has become a bureaucratic paper process acting as a work permit and not functioning as a true evaluation of health [33]. Regardless, it may be prudent during this evaluation also to check these workers for their current level of vaccination (e.g. against Pneumococcus, Haemophilus influenza type $b$ and tetanus toxoid), and according to the type and location of work other vaccines could be considered, where appropriate and feasible [34]. In many ways, this is a forgotten aspect of occupational medicine, especially for those undertaking various forms of abatement. A major role can be played by general practitioners and occupational physicians in terms of health education. These preventive measures can be applied to the construction-related industries in general.

\section{Summary}

The underestimation of the infectious risk among asbestos removers is likely due to the limited number of epidemiological studies on asbestos abatement workers as compared to asbestos workers.

Indeed, as they are exposed to both inorganic/mineral dusts and chemicals, these workers would appear at risk from various forms of infections and communicable diseases. Therefore an evaluation of this population regarding infectious disease occurrence seems to be recommended to determine the extent of this hazard as suggested more broadly by Haagsma [2]. Lastly, abatement workers need to be provided with information on hazards and targeted by appropriate health education to reduce the infection risk.

Competing interests

The authors declare that they have no competing interests. 


\section{Authors' contributions}

JHL conceived the idea and drafted the paper; GM contributed to the drafting of the paper; LC drafted the paper and had general responsibility of the work. All authors read and approved the final manuscript.

\section{Author details}

${ }^{1}$ Envirosafe Training and Consultants, Pittsburgh, PA, USA. ${ }^{2}$ Padua University Department of Molecular Medicine, Padua, Italy. ${ }^{3}$ Imperial College London, School of Public Health, St. Mary's Campus, London, UK

Received: 20 December 2011 Accepted: 1 August 2012

Published: 16 August 2012

\section{References}

1. Torén K, Qvarfordt I, Bergdahl IA, Järvholm B: Increased mortality from infectious pneumonia after occupational exposure to inorganic dust, metal fumes and chemicals. Thorax 2011, 66:992-996.

2. Haagsma JA, Tariq L, Heederik DJ, Havelaar AH: Infectious disease risks associated with occupational exposure: a systematic review of the literature. Occup Environ Med 2011. Online First (10.1136/oemed-2011100068).

3. Cummings KC, McDowell A, Wheeler C, McNary J, Das R, Vugia DJ, MohleBoetani JC: Point-source outbreak of coccidioidomycosis in construction workers. Epidemiol Infect 2010, 138:507-511.

4. Tüchsen F, Hannerz H, Spangenberg S: Mortality and morbidity among bridge and tunnel construction workers who worked long hours and long days constructing the Great Belt Fixed Link. Scand J Work Environ Health 2005, 31(Suppl 2):22-26.

5. Brenner $H$, Ahern $W$ : Sickness absence and early retirement on health grounds in the construction industry in Ireland. Occup Environ Med 2000 57(9):615-620.

6. Harding $\mathrm{AH}$, Darnton A, Osman J: Cardiovascular disease mortality among British asbestos workers (1971-2005). Occup Environ Med 2012. 69:417-421

7. Chen M, Tse LA, Au RK, Yu IT, Wang XR, Lao XQ, Au JS: Mesothelioma and lung cancer mortality: A historical cohort study among asbestosis workers in Hong Kong. Lung Cancer 2011, epub.

8. Williams PR, Phelka AD, Paustenbach DJ: A review of historical exposures to asbestos among skilled craftsmen (1940-2006). J Toxicol Environ Health B Crit Rev 2007, 10:319-377.

9. Turpin-Legendre E, Meyer JP: Comparison of physiological and subjective strain in workers wearing two different protective coveralls for asbestos abatement tasks. Appl Ergon 2003, 34:551-556.

10. Cormack WJ: Infection control during construction. Health Estate 2005, 59:41-43.

11. Rautiala S, Torvinen E, Torkko P, Suomalainen S, Nevalainen A, Kalliokoski $P$, Katila ML: Potentially pathogenic, slow-growing mycobacteria released into workplace air during the remediation of buildings. J Occup Environ Hyg 2004, 1:1-6

12. Cheng SM, Streifel AJ: Infection control considerations during construction activities: land excavation and demolition. Am J Infect Control 2001, 29:321-328.

13. Smith CA: Skin infections in Kaimai Rail Tunnel construction workers. N Z Med J 1977, 85:514-517.

14. Kuruvila M, Dubey S, Gahalaut P: Pattern of skin diseases among migrant construction workers in Mangalore. Indian J Dermatol Venereol Leprol 2006, 72:129-132.

15. Corbett EL, Churchyard GJ, Clayton T, Herselman P, Williams B, Hayes R, Mulder D, De Cock KM: Risk factors for pulmonary mycobacterial disease in South African gold miners. A case-control study. Am J Respir Crit Care Med 1999, 159(1):94-99.

16. Godfrey-Faussett P, Sonnenberg P, Shearer SC, Bruce MC, Mee C, Morris L, Murray J: Tuberculosis control and molecular epidemiology in a South African gold-mining community. Lancet 2000, 356(9235):1066-1071.

17. Sonnenberg P, Glynn JR, Fielding K, Murray J, Godfrey-Faussett P, Shearer S: HIV and pulmonary tuberculosis: the impact goes beyond those infected with HIV. AIDS 2004, 18(4):657-662.

18. Tangkanakul W, Tharmaphornpil P, Plikaytis BD, Bragg S, Poonsuksombat D, Choomkasien P, Kingnate D, Ashford DA: Risk Factors Associated With Leptospirosis In Northeastern Thailand, 1998. Am JTrop Med Hyg 2000 , 63(3, 4):204-208.
19. Katzenelson E, Buium I, Shuval HI: Risk of communicable disease infection associated with wastewater irrigation in agricultural settlements. Science 1976, 194(4268):944-946

20. Archer BN, Weyer J, Paweska J, Nkosi D, Leman P, Tint KS, Blumberg L: Outbreak of Rift Valley fever affecting veterinarians and farmers in South Africa, 2008. S Afr Med J 2011, 101(4):263-266.

21. Thorn J, Beijer $L$, Rylander R: Work related symptoms among sewage workers: a nationwide survey in Sweden. Occup Environ Med 2002, 59:562-566

22. De S, Levesque B, Higgins R, Major M, Laliberté D, Boulianne N, Duval B: Need for vaccination of sewer workers against leptospirosis and hepatitis A. Occup Environ Med 1995, 52:505-507.

23. Arvanitidou M, Constantinidis TC, Doutsos J, Mandraveli K, Katsouyannopoulos $\mathrm{V}$ : Occupational hepatitis B virus infection in sewage workers. Med Lav 1998, 89(5):437-444

24. Franco E, Giambi C, lalacci R, Coppola RC, Zanetti AR: Risk groups for hepatitis A virus infection. Vaccine 2003, 21:2224-2233.

25. O'Shea MK: Acinetobacter in modern warfare. Int J Antimicrob Agents 2012, 39:363-377.

26. Lange $\mathrm{JH}$, Mastrangelo G, Buja A: Smoking and alcohol use in asbestos abatement workers. Bull Environ Contam Toxicol 2006, 77:338-342.

27. Bergdahl IA, Toren K, Eriksson K, Hedlund U, Nissin T, Flodin R, Jarvholm B: Increased mortality in COPD among construction workers exposed to inorganic dust. Eur Respir J 2004, 23:402-406.

28. Skogstad M, Levy F: Occupational irritant contact dermatitis and fungal infection in construction workers. Contact Dermatitis 1994, 31:28-30.

29. Lange $\mathrm{JH}$, Mastrangelo $\mathrm{G}$, Cegolon L: A proposed threshold exposure for airborne asbestos. Occup Environ Med 2011, doi:10.1136/oemed-2011 100225 .

30. Lange $\mathrm{JH}$, Mastrangelo $\mathrm{G}$, Cegolon L: Asbestos abatement workers versus asbestos workers: exposure and health-effects differ. Int J Occup Med Environ Health 2011, 24:1-2

31. Johnson LE, Reyes K, Servos MJ: Resources for Infection Prevention and Control on the World Wide Web. Clin Infect Dis 2009, 48(11):1585-1595.

32. Ohtsu M, Miyamoto H, Yoshioka S, Kajiki S, Ishimatsu S, Ogawa M, Mori K, Taniguchi $\mathrm{H}$ : Construction of a tool for risk assessment of infectious diseases in a workplace-as a primary precaution. J UOEH 2008, 30(4):461-470

33. Lange $\mathrm{JH}$ : A questionnaire survey during asbestos abatement refresher training for frequency of respirator use, respirator fit testing and medical surveillance. J Occup Med Toxicol 1993, 2:65-74.

34. Dos Santos PR, Noronha NH, Mattos UA, da Silva D: Nursing and healthcare for workers: the experience of the immunization action at Fiocruz/Manguinhos. Cien Saude Colet 2011, 16(2):553-565.

doi:10.1186/1471-2458-12-665

Cite this article as: Lange et al:: Infectious disease risk in asbestos abatement workers. BMC Public Health 2012 12:665.

\section{Submit your next manuscript to BioMed Central and take full advantage of:}

- Convenient online submission

- Thorough peer review

- No space constraints or color figure charges

- Immediate publication on acceptance

- Inclusion in PubMed, CAS, Scopus and Google Scholar

- Research which is freely available for redistribution 